\title{
Hierarchical Analysis of Diversity, Selfing, and Genetic Differentiation in Populations of the Oomycete Aphanomyces euteiches
}

\author{
Niklaus J. Grünwald and Gwen-Alyn Hoheisel
}

First author: Horticultural Crops Research Laboratory, U.S. Department of Agriculture-Agricultural Research Service and Department of Botany and Plant Pathology, Oregon State University, 3420 NW Orchard Ave., Corvallis 97330; and second author: Irrigated Agriculture Research and Extension Center, Washington State University, 24106 North Bunn Rd., Prosser 99350.

Accepted for publication 25 May 2006.

\begin{abstract}
Grünwald, N. J., and Hoheisel, G.-A. 2006. Hierarchical analysis of diversity, selfing, and genetic differentiation in populations of the oomycete Aphanomyces euteiches. Phytopathology 96:1134-1141.

Relatively little is known about the population biology of the legume pathogen Aphanomyces euteiches. A. euteiches is a soilborne pathogen causing Aphanomyces root rot of several legumes, including alfalfa, bean, lentil, and pea. Our objectives were to assess the degree of diversity, selfing, and population differentiation in A. euteiches. We contrasted popula-

length polymorphism analysis. Samples of A. euteiches recovered from two fields in northeast Oregon and western Washington confirmed previous reports of moderately high genetic diversity in populations of A. euteiches at the regional scale, but revealed higher-than-expected genotypic diversity within individual soil samples. Populations of A. euteiches were significantly differentiated at the soil sample, field, and regional level. The population structure appears to be patterned by regular selfing via oospores, a mixed reproductive system including both asexual and sexual reproduction, with occasional migration of novel genotypes or outcrossing.
\end{abstract} tions within and among two geographically separated fields with a history of pea production. Molecular genotyping relied on amplified fragment
Additional keyword: recombination.
Our understanding of the recombination and genetic differentiation of plant pathogen populations has improved considerably over the last decade with the advent of molecular genotyping techniques such as amplified fragment length polymorphism (AFLP) or microsatellites and increasingly sophisticated approaches to data analysis. However, relatively little is known about the population biology of the legume pathogen Aphanomyces euteiches Drechs. A. euteiches is a soilborne pathogen causing Aphanomyces root rot of several legumes, including alfalfa, bean, lentil, and pea $(20,46)$. The oomycete genus Aphanomyces is among the smaller and less-studied genera within the family Saprolegniaceae $(52,62)$ that are most closely related to the golden brown algae (28). A. euteiches is diploid and homothallic (27) and readily produces oospores in culture or host tissue. Reproduction in the field results from production of oospores and zoospores.

A. euteiches differs in virulence and pathogenicity depending on the legume host. Pfender and Hagedorn (48) proposed two forma specialis designations for isolates pathogenic to snap bean and pea (A. euteiches f. sp. pisi) and isolates that infect bean but not pea (A. euteiches f. sp. phaseoli). More recent work further distinguished isolates that were pathogenic to the host they were isolated from as well as differing combinations of other hosts such as alfalfa; red, berseem, and crimson clovers; white and

Corresponding author: N. J. Grünwald

E-mail address: Niklaus.Grunwald@ science.oregonstate.edu

* The $\boldsymbol{e}$-Xtra logo stands for "electronic extra" and indicates that the online version contains supplemental material not included in the print edition. The file contains a data set for TFPGA containing AFLP data for all individuals studied that can be executed by describing the data set as containing 56 loci, 2 alleles per locus, 2 populations, and 10 subpopulations for a diploid organism and a dominant marker type.

\section{DOI: 10.1094/PHYTO-96-1134}

This article is in the public domain and not copyrightable. It may be freely reprinted with customary crediting of the source. The American Phytopathological Society, 2006. yellow sweet-clovers; field pea; garden pea; pea and alfalfa; red clover and alfalfa; pea, vetch, and alfalfa; snap bean; lima bean; and faba bean $(18,32,65)$. Reports of isolates of Aphanomyces not specific to any host also exist (32). Variation in pathogenicity within a host genus also has been documented. Further analysis of pathogenicity of $A$. euteiches on pea distinguished 11 virulence types using a set of differential pea lines as well as a differential set of pea cultivars $(66,67)$. In addition, two races of $A$. euteiches currently are distinguished on alfalfa (31). There is also strong support for a genetic basis for pathogenicity phenotype relative to host preference: in a cross of pea and bean pathotypes, this trait has been shown to segregate in F2 progeny (53). A genetic basis also has been established on the host side where several major and minor quantitative trait loci involved in resistance to A. euteiches have been characterized in Pisum sativum $(49,50)$. The picture that emerges from this work is that A. euteiches is a phenotypically heterogeneous species containing different subpopulations with pathogenicity to different hosts or host combinations that has a genetic basis. Thus, a clear understanding of population structure based on genetic marker data would improve the efficacy of breeding programs and deployment of resistance.

Genotypic diversity and population structure also have been investigated, but mostly at the regional scale. Malvick and Percich (33) characterized genetic variation in four populations of A. euteiches sampled in Minnesota, Wisconsin, and Oregon based on random amplified polymorphic DNA (RAPD) analysis. Cluster analysis of genetic similarity among these four populations showed one large cluster containing isolates from all populations. A low level of genotypic variability has been documented for single-zoospore progeny (34), where RAPD analysis revealed genetic variability within two of three groups of single-zoospore progeny examined (34). Although populations of A. euteiches show genetic diversity, it appears that genetic differentiation was not found at the regional level (33) or the zoospore progeny level (34), begging the question of whether populations are differ- 
entiated at the field level or, quite possibly, at the level of the individual soil sample.

Clonal reproduction and selfing are thought to be a common feature in oomycete plant pathogens. Oomycetes can reproduce clonally through formation of asexual sporangia or chlamydospores. Oomycetes also can reproduce sexually through formation of oospores. In contrast to heterothallic oomycetes that require two mating types for sexual reproduction, homothallic species can produce oospores by selfing (9). Homothallic species such as A. euteiches self-fertilize; therefore, we would expect them to be highly inbred. A detailed study of the degree of clonality, selfing, or recombination has not been conducted for A. euteiches. Shang et al. postulated that major variability in A. euteiches most likely originates by outcrossing (54) and demonstrated that outcrossing occurs in controlled experiments (53). Thus, the degree of selfing versus outcrossing remains to be established for $A$. euteiches.

Our objectives were to assess the degree of genotypic diversity, selfing, and population differentiation in contrasting A. euteiches populations within and among two grower's field. We evaluated two hypotheses. First, we expected that populations of A. euteiches would be clonal at the soil sample or field level, given that it is homothallic and presumably selfing. Second, we expected that populations of $A$. euteiches would be well differentiated across and within populations sampled in two fields because the organism is soilborne and cannot migrate freely. AFLP analysis was used to characterize genotypic variation.

\section{MATERIALS AND METHODS}

Sampling. In all, 8 to 10 soil samples of $\approx 4$ liters of soil per sample were collected from two agricultural fields that had a history of Aphanomyces root rot. Both fields had been planted to pea in the year preceding sampling and were planted to wheat in the sampling year. The first field was located near Athena, OR and the second field was located in eastern Washington near Mt. Vernon. These two locations are physically separated by the Cascade Mountains. In all, 5 to 17 isolates were recovered from each individual soil sample, and 10 or 8 soil samples were collected at Athena, OR, and Mt. Vernon, WA, respectively (Table 1). Soil samples were taken by walking on two parallel transects across the field and taking samples every 30 to $50 \mathrm{~m}$.
Isolations, culturing, and DNA extractions. Isolates were obtained using the wet-sieving/baiting technique (26). Briefly, a 100-g subsample of each soil sample was screened through a 10mesh screen (2-mm opening) and homogenized for $3 \mathrm{~min}$ in a blender with $500 \mathrm{ml}$ of sterile distilled water. The organic debris recovered was used to bait $A$. euteiches using the taproot of pea seedlings. A. euteiches was recovered by plating a surfacesterilized root section on corn meal agar. Isolates were maintained short term on cornmeal agar or long term as agar plugs placed in sterile water in screw-cap vials.

Previous work reported that single-zoospore isolates could loose pathogenicity or change genotype $(25,34)$. To assess whether cultures were mixed or whether single-spore progeny changed AFLP genotype compared with parental strains, three to five single-zoospore isolates were obtained for each of five isolates. Single-zoospore progeny were obtained as described by Mitchell and Yang (42) by spreading zoospores on agar media and subculturing single, isolated, germinating zoospores cysts. Each progeny isolate for each of the five parental strains directly baited from soils was analyzed for AFLP genotype. All experiments were repeated three times with independent DNA extractions and polymerase chain reaction (PCR) reactions for all progeny and parental isolates.

To obtain mycelium for DNA extraction, cultures were inoculated with 5 -mm-diameter agar plugs added to $100 \mathrm{ml}$ of potato dextrose broth (Difco Laboratories, Detroit) in 250-ml Erlenmeyer flasks. Cultures were incubated at room temperature (20 to $22^{\circ} \mathrm{C}$ ) for 7 to 10 days on a rotary shaker at $\approx 90 \mathrm{rpm}$. Mycelium was collected and blotted dry on filter paper followed by DNA extraction using the FastDNA kit (QBiogene, Carlsbad, CA).

AFLP genotyping. AFLP (61) was performed on genomic DNA of A. euteiches using the AFLP Microbial Fingerprinting protocol (Applied Biosystems, Foster City, CA) with slight modifications. DNA (20 ng) was digested and adaptors were ligated in an 11- $\mu$ l reaction volume with EcoRI (5 U), MseI (1 U), T4 DNA ligase (1 Weiss U), $1.0 \mu \mathrm{l}$ of $M s e \mathrm{I}$ and EcoRI adaptor, $1.1 \mu \mathrm{l}$ of $0.5 \mathrm{M} \mathrm{NaCl}, 0.5 \mu \mathrm{l}$ of bovine serum albumen (BSA; $1.0 \mathrm{mg} / \mathrm{ml}$ ), and $1.1 \mu \mathrm{l}$ of $10 \times \mathrm{T} 4 \mathrm{DNA}$ ligase buffer (50 mM Tris$\mathrm{HCl}, \mathrm{pH} 7.8,10 \mathrm{mM} \mathrm{MgCl} 2,10 \mathrm{mM}$ dithiothreitol, $1 \mathrm{mM}$ ATP, and BSA at $25 \mu \mathrm{g} / \mathrm{ml}$ ) (New England Biolabs, Beverly, MA) for $2 \mathrm{~h}$ at $37^{\circ} \mathrm{C}$. Restriction-ligation samples were diluted 1:4 with

TABLE 1. Origin, sample sizes, and amplified fragment length polymorphism genotypes observed of Aphanomyces euteiches isolates characterized for genotype in two populations ${ }^{\mathrm{a}}$

\begin{tabular}{|c|c|c|c|c|c|c|c|c|}
\hline Location & Field (population) & Soil sample (subpopulation) & $n$ & $P(\%)$ & $g_{\text {obs }}$ & $G$ & $E_{5}$ & $\hat{h}$ \\
\hline Athena, OR & 1 & 1 & 9 & 26.8 & 7 & 6.2 & 0.93 & 0.096 \\
\hline Athena, OR & 1 & 2 & 12 & 60.7 & 12 & 12.0 & 1.0 & 0.268 \\
\hline Athena, OR & 1 & 3 & 10 & 5.4 & 2 & 1.2 & 0.57 & 0.013 \\
\hline Athena, OR & 1 & 4 & 13 & 28.6 & 9 & 5.1 & 0.69 & 0.086 \\
\hline Athena, OR & 1 & 5 & 10 & 25.0 & 7 & 5.6 & 0.89 & 0.084 \\
\hline Athena, OR & 1 & 6 & 5 & 25.0 & 5 & 5.0 & 1.0 & 0.096 \\
\hline Athena, OR & 1 & 7 & 11 & 46.4 & 10 & 9.3 & 0.96 & 0.155 \\
\hline Athena, OR & 1 & 8 & 8 & 23.2 & 6 & 4.6 & 0.83 & 0.061 \\
\hline Athena, OR & 1 & 9 & 10 & 44.6 & 10 & 10.0 & 1.0 & 0.148 \\
\hline Athena, OR & 1 & 10 & 9 & 39.3 & 8 & 7.4 & 0.95 & 0.096 \\
\hline Mt. Vernon, WA & 2 & 1 & 10 & 48.2 & 9 & 8.3 & 0.97 & 0.131 \\
\hline Mt. Vernon, WA & 2 & 2 & 6 & 76.8 & 6 & 6.0 & 1.0 & 0.359 \\
\hline Mt. Vernon, WA & 2 & 3 & 8 & 37.5 & 6 & 4.6 & 0.83 & 0.101 \\
\hline Mt. Vernon, WA & 2 & 4 & 12 & 23.2 & 8 & 4.5 & 0.68 & 0.062 \\
\hline Mt. Vernon, WA & 2 & 5 & 17 & 16.1 & 7 & 5.1 & 0.85 & 0.040 \\
\hline Mt. Vernon, WA & 2 & 6 & 12 & 76.8 & 11 & 10.3 & 0.96 & 0.262 \\
\hline Mt. Vernon, WA & 2 & 7 & 12 & 16.1 & 9 & 7.2 & 0.87 & 0.044 \\
\hline Mt. Vernon, WA & 2 & 8 & 13 & 14.3 & 9 & 6.3 & 0.79 & 0.043 \\
\hline Average & $\ldots$ & $\ldots$ & 10.4 & 35.2 & 7.8 & 6.6 & 0.88 & 0.119 \\
\hline
\end{tabular}

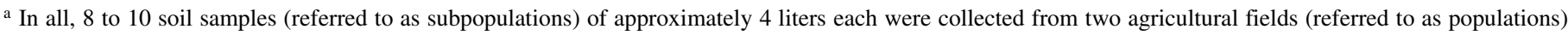
that had a history of Aphanomyces root rot. Both fields had been planted to peas in the year preceding sampling. These two locations are physically separated by the Cascade Mountains. Abbreviations: $n=$ sample size, $P=$ percentage of loci that are polymorphic, $g_{\text {obs }}=$ number of genotypes observed, $G=$ multilocus genotypic diversity based on Stoddard and Taylor's index (57), $E_{5}=$ evenness $(23,29)$, and $\hat{h}=$ Nei's gene diversity, also referred to as heterozygosity, calculated to adjust for selfing in analogy to unbiased expected heterozygosity $(44,45)$. 
sterile deionized water. Preselective amplifications totaling a $10-\mu \mathrm{l}$ reaction of $3.0 \mu \mathrm{l}$ of restriction-ligation sample with $0.25 \mu \mathrm{l}$ of EcoRI core primer, $0.25 \mu \mathrm{l}$ of $\mathrm{Mse}$ I core primer, and $3.25 \mu \mathrm{l}$ of AFLP amplification core mix (Applied Biosystems) were performed on a GeneAmp 9700 thermal cycler (Applied Biosystems) programmed as follows: $2 \mathrm{~min}$ at $72^{\circ} \mathrm{C} ; 20$ cycles of $20 \mathrm{~s}$ at $94^{\circ} \mathrm{C}$, $30 \mathrm{~s}$ at $56^{\circ} \mathrm{C}$, and $2 \mathrm{~min}$ at $72^{\circ} \mathrm{C}$; and cooling to $4^{\circ} \mathrm{C}$. Amplicons $(10 \mu \mathrm{l})$ were checked on $1.2 \%$ agarose gels $(4 \mathrm{~V} / \mathrm{cm}$ for 3 to $4 \mathrm{~h})$ in $1 \times$ Tris-borate EDTA buffer and visualized with ethidium bromide and UV illumination. Preamplified samples (10 $\mu$ l) were diluted 1:8 with sterile deionized water. Selective PCR was performed on $1.5 \mu \mathrm{l}$ of diluted, preamplified product in a $10-\mu \mathrm{l}$ reaction volume with $0.5 \mu \mathrm{l}$ of $\mathrm{Mse}$ I-CT primer at $5 \mu \mathrm{M}, 0.5 \mu \mathrm{l}$ of dye-labeled EcoRI-AT primer at $1 \mu \mathrm{M}$, and $3.75 \mu \mathrm{l}$ of AFLP core amplification mix (Applied Biosystems). Reactions were performed under the following conditions: $2 \mathrm{~min}$ at $94^{\circ} \mathrm{C}$; 10 cycles of $20 \mathrm{~s}$ at $94^{\circ} \mathrm{C}, 30 \mathrm{~s}$ at $66^{\circ} \mathrm{C}$, and $2 \mathrm{~min}$ at $72^{\circ} \mathrm{C}$ (annealing temperature lowered by $1^{\circ} \mathrm{C}$ during each cycle); followed by 20 cycles of $20 \mathrm{~s}$ at $94^{\circ} \mathrm{C}, 30 \mathrm{~s}$ at $56^{\circ} \mathrm{C}$, and $2 \mathrm{~min}$. at $72^{\circ} \mathrm{C}$; and a final extension for $30 \mathrm{~min}$ at $60^{\circ} \mathrm{C}$ and cooling to $4^{\circ} \mathrm{C}$. Products $(1.0 \mu \mathrm{l})$ were run with $10 \mu \mathrm{l}$ of loading buffer $(9.8 \mu \mathrm{l}$ of deionized formamide and $0.2 \mu \mathrm{l}$ of GeneScan-500 size standard) (Applied Biosystems) on a capillary sequencer (ABI Prism 310 or 3100; Applied Biosystems). Samples were run in a $36-\mathrm{cm} \mu \mathrm{m}$ capillary with POP-4 polymer. Samples were injected for $12 \mathrm{~s}$ at $15 \mathrm{kV}$ and run at $13 \mathrm{kV}$ for $34 \mathrm{~min}$ at $60^{\circ} \mathrm{C}$. Electropherograms were analyzed using GeneMapper software (version 3.7; Applied Biosystems) to extract a matrix of presence and absence of alleles in a range of 100 to $500 \mathrm{bp}$ after visual inspection for further downstream analysis. All AFLP analyses were replicated two or more times, including independent DNA extractions and PCR reactions, until all polymorphic alleles could be unambiguously binned.

Data analysis. Population structure was studied by analyzing allele frequencies, gene diversity, genetic distance, clonality, and genetic differentiation. A multilocus genotype was constructed for each isolate by combining data for single AFLP alleles (23). Alleles were treated as dominant markers and frequencies were estimated based on Lynch and Milligan's Taylor expansion estimate (30). Of the 144 alleles scored, only 56 were retained for analysis after removing rare ( $<3 \%$ frequency) or fixed alleles. To assess the effect of clonality on our estimates of population genetic variation, analyses were conducted on a data set including all individuals and a data set including one member of each distinct multilocus genotype for each subpopulation (i.e., clone corrected) (41).

Nei's gene diversity $\hat{h}$, also referred to as heterozygosity (44, 45), was calculated to adjust for selfing. Nei's gene diversity is particularly useful given that it is applicable to organisms of different ploidy levels or reproductive systems, including selfing (24). The $\hat{h}$ was calculated in Tools for Population Genetic Analyses (TFPGA; version 1.3; Department of Biological Sciences, Northern Arizona University, Flagstaff) and adjusted for selfing by multiplication with $(n-1) / n$, where $n$ equals sample size (45). For $n>50$, no correction was necessary $(44,45)$.

Cluster analysis was based on allele frequencies observed for populations or subpopulations. Trees were constructed using the unweighted pairgroup method of averages (UPGMA) algorithm from Nei's genetic distance matrix $(43,44)$. Statistical support for phenogram branches was obtained using 2,000 bootstrapped samples using TFPGA.

Multilocus genotypic diversity analysis for the overall population and subpopulations distinguished richness, evenness, and diversity $(22,23)$ using SAS (SAS Institute, Cary, NC) as described previously $(22,23)$. Briefly, genotypic diversity was calculated as Stoddard and Taylor's index $G=1 / \sum p_{i}^{2}(57)$. $G$ is dependent on sample size, because more genotypes are observed in larger sample sizes; therefore, it was scaled by the number of expected genotypes $\left(g_{90}\right)$ estimated using rarefaction as described previously (23). $G / g_{90}$ is a measure of evenness because the effect of richness is removed. Evenness also was calculated as $E_{5}(29)$, where

$$
E_{5}=\frac{(1 / \hat{\lambda})-1}{e^{H^{\prime}}-1}
$$

and $\hat{\lambda}$ corresponded to Simpson's index (56)

$$
\hat{\lambda}=\sum_{i-1}^{g} \frac{n_{i}\left(n_{i}-1\right)}{n(n-1)}
$$

where $n_{\mathrm{i}}$ equals the number of observations of the $i$ th genotype and $n$ equals sample size. Genotypic richness $\left(g_{n}\right)$ expressed the number of expected genotypes in a sample for given sample size $n$ and was estimated using rarefaction curves (29) using an algorithm implemented in the $\mathrm{C}$ computer language, as described previously $(22,23)$.

Population genetic structure was analyzed further by conducting an analysis of molecular variance (AMOVA) (10) using Arlequin (version 2.0) (51). This approach is derived from the analysis of variance framework based on Wright's fixation indices as defined by Cockerham $(7,8)$. A hierarchical analysis of variance was conducted to partition variance into covariance components due to intra-individual, intersubpopulation, and interpopulation differences. Covariance components are used to calculate $\Phi$ fixation indices $(63,69)$. Significance of fixation indices was tested using 1,000 nonparametric permutations.

To assess whether genotypes were related across the two populations, a minimum-length spanning network of all unique AFLP genotypes found among the 18 subpopulations was constructed based on Nei's genetic distance (44) using NTSYSpc (version 2.1; Applied Biostatistics Inc., New York). Module MST was used to calculate the graphing matrix relating nearest neighbors, while module MDSCALE was used for ordination in two-dimensional space.

To assess the relative contribution of selfing (or clonality) and recombination, we used two approaches applied to both nonclone-corrected and clone-corrected populations $(36,59)$. Both of these methods assume that all alleles observed have the same evolutionary histories under selfing or clonality, but that alleles from different regions have different histories under recombination. First, associations among AFLP loci were tested using the index of association $\left(I_{A}\right)$ statistic (3) as implemented in the program MULTILOCUS (version 1.2.2) (4). $I_{A}$ is based on analysis of genetic distances among multilocus genotypes and calculates the variance of distances between all possible pairs of multilocus genotypes, which is low for recombining and high for clonal or selfed populations. To assess significance, alleles were randomly permuted 1,000 times among individuals. Second, the parsimony tree-length permutation test (PTLPT) derived from phylogenetics was used to determine significance by comparing the length of the tree of the observed data to the distribution of tree lengths of 1,000 permuted data sets (as described for $I_{A}$ ) (4). Phylogenetic trees were built from the multilocus genotypes using parsimony in PAUP version 4.0 (58) using an input file generated from MULTILOCUS. For selfed or clonal populations, the observed tree length should be significantly shorter than the distribution of tree lengths under the null hypothesis of random mating.

\section{RESULTS}

AFLP analysis. AFLP analysis showed extensive polymorphisms among isolates from the two populations and 18 subpopulations studied (Tables 1 and 2). In all, 56 polymorphic loci were obtained with the EcoRI-AT/MseI-CT primer combination with an observed gene diversity of 0.314 for the 187 isolates of A. euteiches analyzed. All loci were polymorphic at the $99 \%$ criterion and distinguished a total of 119 distinct multilocus genotypes. All 56 alleles could be binned unambiguously based 
on two or more independent PCR and electrophoresis runs. Percentage of polymorphic loci ranged from 5.4 for a clonal subpopulation with only two genotypes to a maximum of 76.8 , and averaged 35\% across all subpopulations (Table 1).

Single-zoospore progeny. Analysis of three to five singlezoospore isolates obtained for each of five parental isolates revealed few differences among the parental isolates and the singlezoospore progeny. An example of identical electropherograms observed for isolate Ae $02 \mathrm{C} 5$ and three progeny strains is shown in Figure 1. In three cases, no differences were found among the parental and progeny strains. In one case, one allele and, in another case, three alleles were present in one or several progeny strains, but not in the parental strain. Thus, frequencies for polymorphic loci ranged from 0 to $3.6 \%$ for variation among singlezoospore progeny, which was well below the level detected for subpopulations from individual soil samples that averaged $35 \%$ (Table 1).

Diversity within soil samples. Each soil sample baited harbored a genotypically diverse population. On average, we detected 7.8 genotypes out of 10.4 isolates sampled, showing that $75 \%$ of isolates belonged to a unique genotype (Table 1). Genotypic diversity $G$ ranged from 1.2 for a subpopulation with only two genotypes to 12 in a population where each of the individuals sampled belonged to a different genotype, and averaged 6.6 for all samples (Table 1). Evenness ranged from 0.57 to 1.0 and averaged 0.88 and showed that genotypes were fairly evenly distributed (Table 1). Gene diversity for subpopulations ranged from 0.013 to 0.359 , averaging 0.119 (Table 1 ).

Population genotypic diversity and differentiation. The Athena and Mt. Vernon populations had $70(72 \%)$ and $50(56 \%)$

TABLE 2. Population genotypic diversity measures for populations including all individuals or corrected for clones occurring within each subpopulation ${ }^{\mathrm{a}}$

\begin{tabular}{|c|c|c|c|c|c|c|c|c|c|c|c|c|c|}
\hline \multirow[b]{2}{*}{ Population } & \multicolumn{9}{|c|}{ All individuals } & \multicolumn{4}{|c|}{ Clone-corrected analysis } \\
\hline & $n$ & $g_{\text {obs }}$ & $g_{90}$ & $G$ & $G / g_{90}$ & $E_{5}$ & $\hat{h}$ & $I_{A}$ & PTLPT & $n$ & $\hat{h}$ & $I_{A}$ & $P T L P T$ \\
\hline Athena & 97 & 70 & 69.9 & 42.2 & 0.60 & 0.72 & 0.17 & $2.91 * * *$ & $<0.001$ & 76 & 0.19 & $2.55 * * *$ & $<0.001$ \\
\hline Mt. Vernon & 90 & 50 & 49.9 & 28.7 & 0.58 & 0.73 & 0.19 & $13.3 * * *$ & $<0.001$ & 65 & 0.21 & $14.3 * * *$ & $<0.001$ \\
\hline
\end{tabular}

a Data is based on amplified fragment length polymorphism data of two Aphanomyces euteiches populations consisting of 10 subpopulations in Athena, OR and 8 subpopulations in Mt. Vernon, WA. Abbreviations: $n=$ sample size, $g_{\text {obs }}=$ number of genotypes observed, $g_{90}=$ number of genotypes expected for the common sample size of $n=90$ calculated by using the rarefaction method $(22,23,55), G=$ multilocus genotypic diversity based on Stoddard and Taylor's index (57), $G / g_{90}=$ evenness calculated by scaling Stoddard and Taylor's index (57) by number of expected genotypes $g_{90}$ to adjust for sample size dependence as described previously (23), $E_{5}=$ evenness $(23,29), \hat{h}=$ Nei's gene diversity, also referred to as heterozygosity, calculated to adjust for selfing in analogy to unbiased expected heterozygosity $(44,45), I_{A}=$ index of association $(3,4)$ where $* * *$ reflects $P<0.001$ based on 1,000 permuted data sets, and PTLPT $=$ parsimony tree length permutation test (4), where significance level of PTLPT is based on comparison of length of observed parsimony tree to lengths of trees generated from 1,000 permuted data sets (4).
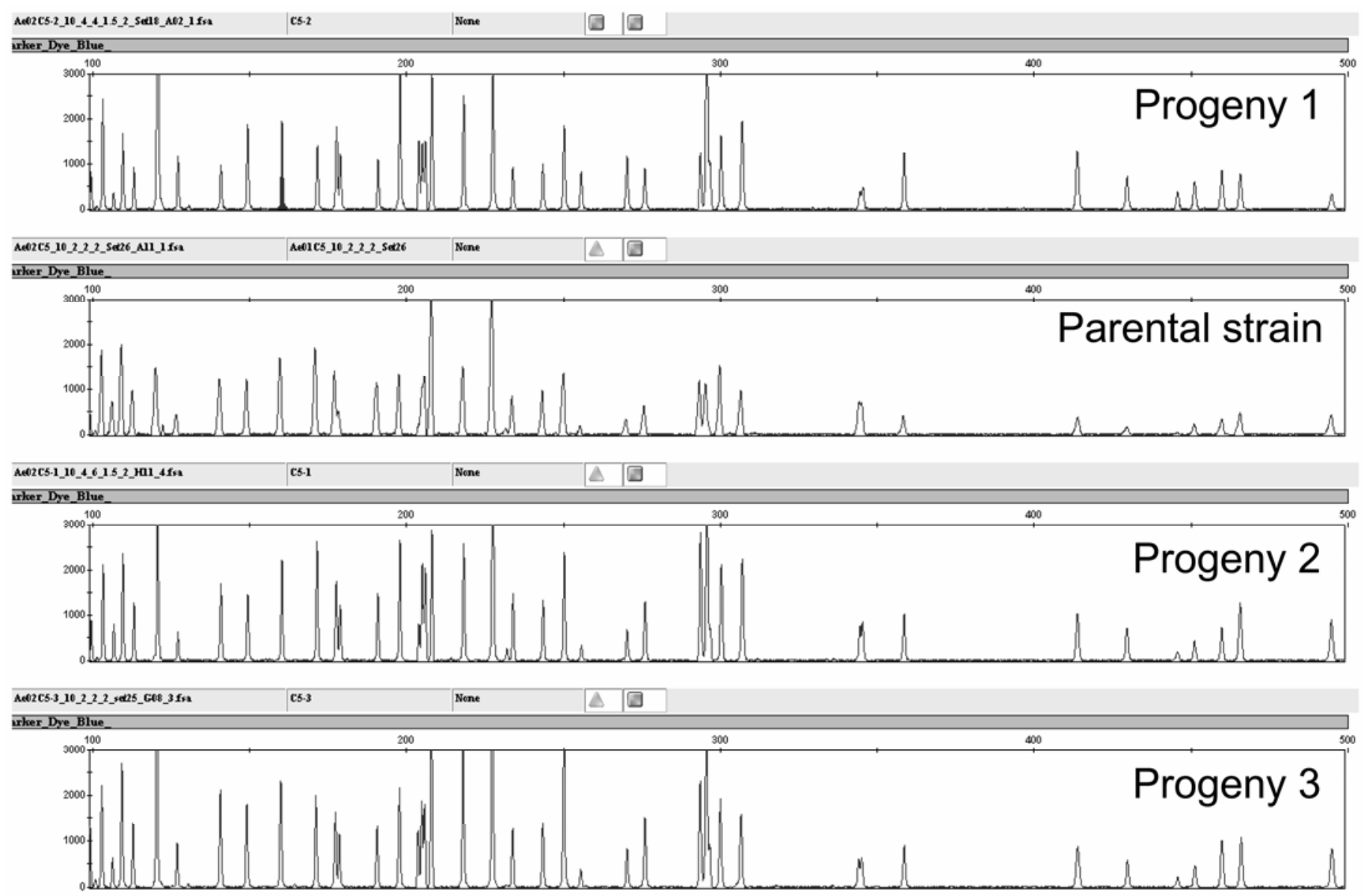

Fig. 1. Electropherograms showing identical amplified fragment length polymorphism profiles of genomic DNA for one parental strain and three single-zoospore isolates of Aphanomyces euteiches. 
unique genotypes out of 97 and 90 isolates sampled, respectively (Table 2). Richness (as calculated for a sample size of 90 individuals) and genotypic diversity were lower in the Mt. Vernon population, whereas evenness (i.e., both $G / g_{90}$ and $E_{5}$ ) was similar in both individual populations and the combined population (Table 2). Gene diversity was high across the two populations and moderate within each population, and was not affected by clone correction (Table 2).

Populations were significantly differentiated among populations, among subpopulations within populations, and within subpopulations whether analysis was done including all individuals or including clone-corrected populations $(P<0.0001)$ (Table 3$)$. A total of $70 \%$ of the variance was associated with differences among populations and $22 \%$ with differences within populations, whereas only $8 \%$ of the variance was attributable to variation among subpopulations within populations (Table 3). Fixation indices were high but were lowest among subpopulations within populations (Table 3 ). The significant population differentiation also was apparent in the bootstrap support and the genetic distance analysis presented in Figure 2.

Comparative analysis of the clone-corrected and total population resulted in qualitatively similar results. Gene diversity, genetic distance, and population differentiation remained qualitatively similar in the clone-corrected analysis (Tables 2 and 3; Fig. 2).

To describe relationships among AFLP clones, a minimumspanning length network was constructed. With minor exceptions, all genotypes clustered in either the Mt. Vernon or Athena population. Multilocus genotype 61 was observed in both the Athena and Mt. Vernon populations. Genotypes 62, 65, 64, and 5 belonged to the Mt. Vernon population but were placed with the Athena population. Thus, genotype placement confirmed the significant differentiation among populations.

Selfing and clonality. The population of A. euteiches, despite being genetically diverse given the large number of multilocus genotypes observed, appears to be selfed. The tests for multilocus association $\left(I_{A}\right)$ all were significantly different from zero $(P<$ $0.001)$, revealing that there is linkage disequilibrium in all populations (Table 2). The $I_{A}$ values ranged from 2.9 to 14.4 in the populations including all individuals and 2.6 to 13.8 in the clonecorrected populations (Table 2). Phylogenetic analysis based on $P T L P T$ revealed a tree length for the observed data that was significantly shorter than expected for recombining organisms for both total and clone-corrected data sets $(P<0.001)$ (Table 2$)$. These results support rejection of the hypothesis of random mating and, instead, lend support to a hypothesis of selfing and the presence of a mixed reproductive system (asexual, selfing, occasionally outcrossing, parasexual, or sexual).

\section{DISCUSSION}

Our observations confirmed previous reports of moderately high genetic diversity in populations of A. euteiches at the re- gional scale, but revealed higher-than-expected genotypic diversity within individual soil samples $(32,33,64)$. Recent work using similar methodology studied genotypic diversity of $A$. euteiches based on AFLP analysis (64). This work showed similar levels of genotypic diversity based on the Shannon-Wiener index $\left(H^{\prime}\right.$ ranged between 0.40 and 0.48 for different populations). The populations from Mt. Vernon or Athena were as genotypically diverse as were the global populations Wicker (64) analyzed. Our study shows that, at the level of the individual soil sample, approximately representing the soil volume a typical pea plant might explore, there is considerable genotypic diversity given that, on average, 8 of 10 individuals retrieved from a soil sample were of a unique genotype.

Populations of A. euteiches in Athena and Mt. Vernon were significantly differentiated both at the regional (among populations)

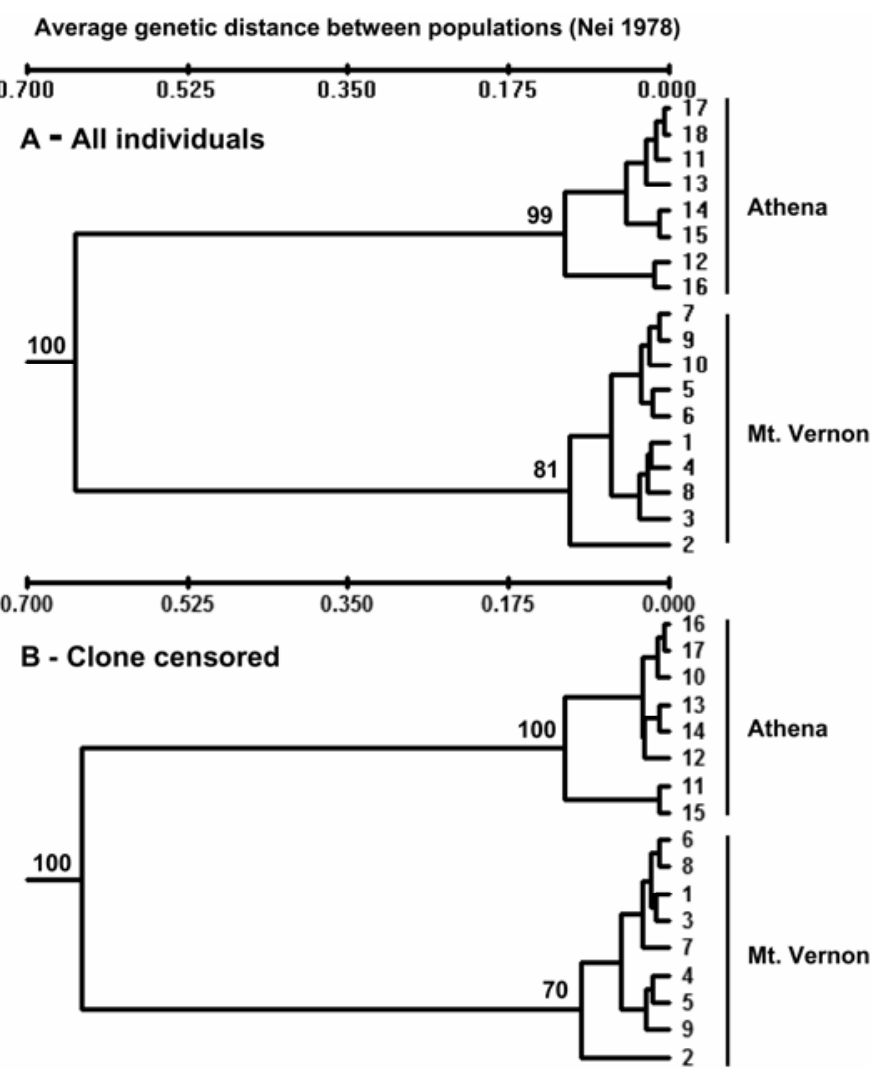

Fig. 2. Relationship between the Aphanomyces euteiches populations in Athena (east of the Cascade range) and Mt. Vernon (west of the Cascade range) based on Nei's genetic distance (44) calculated for amplified fragment length polymorphism allele frequencies based on $\mathbf{A}$, all individuals sampled and $\mathbf{B}$, a clone-corrected data set containing only genotypes unique to each subpopulation. Numbers at major branches indicate statistical support for phenogram branches using 2,000 bootstrapped samples.

TABLE 3. Analysis of molecular variance for amplified fragment length polymorphism data of two Aphanomyces euteiches populations in Athena, OR, and Mt. Vernon, $\mathrm{WA}^{\mathrm{a}}$

\begin{tabular}{lccc}
\hline Hierarchical level & Variation $(\%)$ & $\Phi$ & $P$ \\
\hline Analysis of all individuals & & & \\
$\Phi_{\mathrm{CT}}$ (among populations) & 70.01 & 0.70 & $<0.0001^{\mathrm{b}}$ \\
$\Phi_{\mathrm{SC}}$ (among subpopulations within populations) & 8.41 & 0.28 & $<0.0001^{\mathrm{c}}$ \\
$\Phi_{\mathrm{ST}}$ (within subpopulations) & 21.59 & 0.78 & $<0.0001^{\mathrm{d}}$ \\
Clone-corrected analysis & & & $<0.67$ \\
$\Phi_{\mathrm{CT}}$ (among populations) & 66.68 & 0.18 & $<0.0001^{\mathrm{b}}$ \\
$\Phi_{\mathrm{SC}}$ (among subpopulations within populations) & 6.10 & 0.73 & $<0.0001^{\mathrm{c}}$ \\
$\Phi_{\mathrm{ST}}$ (within subpopulations) & 27.22 & \\
\hline
\end{tabular}

${ }^{a}$ Variance was partitioned among and within two populations and within 10 (Athena) or 8 (Mt. Vernon) subpopulations.

${ }^{\mathrm{b}}$ Probability of obtaining equal or lower $\Phi$ value determined by 1,000 randomizations by permuting subpopulations among populations.

${ }^{\mathrm{c}}$ Probability of obtaining equal or lower $\Phi$ value determined by 1,000 randomizations by permuting haplotypes among subpopulations within populations.

${ }^{\mathrm{d}}$ Probability of obtaining equal or lower $\Phi$ value determined by 1,000 randomizations by permuting haplotypes among subpopulations among populations. 
and field (within populations and among subpopulations) level. In fact, only one genotype was shared among the two populations. Malvick and Percich (33) previously had hypothesized that most genotypic diversity in U.S. populations in the Midwest and Northwest may exist within localized populations. Our sampling allowed partitioning of variation among populations (70\%), among subpopulations within populations (8\%), and within subpopulations $(22 \%)$ (Table 3$)$. Thus, most variation was seen at the regional scale, yet considerable variation was present at the level of the soil sample. To ensure that the high levels of genotypic diversity observed were real, care was taken throughout this study to score only alleles that could be replicated in independent PCR and electrophoresis runs.

One question raised during conduct of this work was whether it was really necessary to obtain single-spore isolates to investigate population structure. Malvick and Percich investigated genotypic variation among single-zoospore progeny using RAPD analysis (34). This work was based on progeny derived from three parental strains. For one of the strains, all single-zoospore progeny were identical in genotype to the parental strain. For the other two isolates, polymorphic bands were detected at low frequency. Our work revealed a similarly low level of polymorphism among progeny and parental strains. If rare alleles are removed from the analysis, it appears that single-spore isolations, which are timeconsuming, are not necessary. Work by several laboratories indicated that isolates from single-zoospore progeny of oomycetes can show changes in phenotype and either show the same level of aggressiveness or lose aggressiveness relative to the parental strain $(1,6,34)$. Thus, it appears that basing pathogenicity studies on single-zoospore progeny would have the effect of underestimating pathogenicity of the field population. Given these considerations, the need for single-spore isolation for population genetic studies evaluating differentiation using molecular marker data might not be necessary for A. euteiches given the considerable degree of genotypic variation observed in the overall population relative to single-zoospore progeny. This is in agreement with studies of other oomycete plant pathogens, where it is common practice that an isolate derived from a single, discrete lesion is considered to be one individual $(11,14,16)$.

Several considerations could explain why novel alleles are or are not observed in single-zoospore progeny. First, not all primer combinations might result in detection of variable genotypes. For example, Malvick and Percich established that some of the RAPD primer combinations did not result in detection of polymorphism among parental and progeny strains. Our AFLP work was based on only one primer combination and resulted in 56 scored, polymorphic alleles. Second, technical artifacts such as mispriming, particularly in RAPDs, are known to be sensitive to experimental factors. This does not appear to be the case in the work conducted by Malvick and Percich (34) because extreme care was taken to assure reproducibility of the work. Although bands varying in intensity were detected, these were not included in the analysis. These authors carefully replicated all RAPD analysis of progeny strains with genotypes differing from parental strains. In our work, all AFLP runs were independently replicated two or more times until all alleles could be unambiguously binned. Third, variability in single-zoospore progeny does not occur at the same frequency for all parental strains. At least one parental strain studied by Malvick and Percich (34) and by us did not reveal a novel allele in its progeny. Fourth, the mechanism involved in creating novel alleles is likely to be a mutation affecting an EcoRI or MseI restriction site or fragment size variation due to point mutations.

This study provides strong evidence for selfing, but inferences about the degree of outcrossing remain less convincing. Shang et al. clearly demonstrated that $A$. euteiches can reproduce via oospores through either self-fertilization or cross-fertilization (53). In our study, gene diversity in A. euteiches ranged between
0.2 and 0.3 for clone-corrected populations and, thus, was quite similar to outcrossing, heterothallic oomycetes such as Phytophthora infestans (at the center of origin) or P. palmivora, but considerably different to that of homothallic Phytophthora spp. that typically have observed gene diversities (i.e., heterozygosities) below $0.06(11,15,21,22)$. The homothallic oomycete Pythium ultimum has been shown to outcross at rates of 1 to $10 \%$ in oospore progeny of controlled laboratory crosses $(12,13)$. In controlled crosses with $A$. euteiches, Shang et al. established that only $\approx 5 \%$ of germinated oospores were hybrids, whereas $95 \%$ percent were selfed (53). In this study, index of association $\left(I_{A}\right)$ and PTLPT confirmed the genetic isolation between the two populations and within subpopulations, showing that selfing is in effect. Work by Wicker also showed evidence of selfing for A. euteiches populations in France based on $I_{A}$ (64). The signal for selfing might derive from reproduction via both oospores (selfed or recombined) and clonality via zoospores (asexual).

Which forces, then, explain the variation observed in A. euteiches populations? The occurrence of sexual recombination has been described for controlled crosses (53) and is likely to occur in the field, although probably at low frequency. A significant signal for selfed reproduction via oospores was detected. One multilocus genotype was shared among populations and four genotypes were assigned into a geographically distant population, thus providing evidence for migration of individuals. Yet the data presented here, showing that there is considerable genotypic variation even at the soil sample level coupled with significant population substructuring, provide circumstantial evidence that outcrossing and migration occur, albeit rarely, and contribute to genetic diversity and population differentiation.

It appears that the model best describing the population structure of A. euteiches is a variation of the epidemic model discussed by Maynard Smith et al. $(36,39)$, where occasional outcrossing via ("non-selfed") sexual recombination provides for allele richness, but selfed recombination via oospores or clonal reproduction via zoospores results in the linkage associations observed. This is similar to a population structure due to mixed modes of reproduction or mating that include clonality, selfing, and recombination as observed for other fungi and oomycetes $(2,5,15$, $17,21,22,35,37,38,40,47,60,70)$. As a result of the soilborne nature and the lack of a mechanism for routine long-distance dispersal, A. euteiches can outcross only with highly localized individuals from the same "genetic neighborhood" (68) due to isolation by distance. This neighborhood likely is located in the same agricultural field or local ecosystem. Given the rare, random mating within neighborhoods, and the diffuse spatial boundaries to these neighborhoods, the population appears to be inbreeding and at linkage disequilibrium.

\section{ACKNOWLEDGMENTS}

A preliminary analysis of work in progress based on partial data was presented previously at the Second International Aphanomyces Workshop (19). We thank D. Inglis for facilitating sampling of soils in Mt. Vernon, WA; V. Coffman for making the isolations and maintaining the cultures; G. Vandemark for providing reference isolates of A. euteiches; and L. Porter, M. Milgroom, and the anonymous reviewers for many valuable comments on earlier drafts of this manuscript.

\section{LITERATURE CITED}

1. Abu-El Samen, F. M., Secor, G. A., and Gudmestad, N. C. 2003. Variability in virulence among asexual progenies of Phytophthora infestans. Phytopathology 93:293-304.

2. Bock, C. H., Thrall, P. H., and Burdon, J. J. 2005. Genetic structure of populations of Alternaria brassicicola suggests the occurrence of sexual recombination. Mycol. Res. 109:227-236.

3. Brown, A. H. D., Feldman, M. W., and Nevo, E. 1980. Multilocus structure of natural populations of Hordeum spontaneum. Genetics 96:523-536. 
4. Burt, A., Carter, D. A., Koenig, G. L., White, T. J., and Taylor, J. W. 1996. Molecular markers reveal cryptic sex in the human pathogen Coccidioides immitis. Proc. Natl. Acad. Sci. USA 93:523-536.

5. Carbone, I., Anderson, J. B., and Kohn, L. M. 1999. Patterns of descent in clonal lineages and their multilocus fingerprints are resolved with combined gene genealogies. Evolution 53:11-21.

6. Caten, C. E., and Jinks, J. L. 1968. Spontaneous variability of single isolates of Phytophthora infestans. I. Cultural variation. Can. J. Bot. 46:329-348.

7. Cockerham, C. C. 1969 . Variance of gene frequencies. Evolution 23:72-83.

8. Cockerham, C. C. 1973. Analyses of gene frequencies. Genetics 74:679700 .

9. Erwin, D. C., and Ribeiro, O. K. 1996. Phytophthora Diseases Worldwide. The American Phytopathological Society, St. Paul, MN.

10. Excoffier, L., Smouse, P. E., and Quattro, J. M. 1992. Analysis of molecular variance inferred from metric distances among DNA haplotypes: Application to human mitochondrial DNA restriction data. Genetics 131:479-491.

11. Flier, W. G., Grünwald, N. J., Kroon, L. P. N. M., Sturbaum, A. K., van den Bosch, G. B. M., Garay-Serrano, E., Fry, W. E., and Turkensteen, L. J. 2003. The population structure of Phytophthora infestans from the Toluca Valley in central Mexico suggests genetic differentiation between populations from cultivated potato and wild Solanum species. Phytopathology 93:382-390.

12. Francis, D. M., and St. Clair, D. A. 1993. Outcrossing in the homothallic oomycete, Pythium ultimum, detected with molecular markers. Curr. Genet. 24:100-106.

13. Francis, D. M., and St. Clair, D. A. 1997. Population genetics of Pythium ultimum. Phytopathology 87:454-461.

14. Garzón, C. D., Geiser, D. M., and Moorman, G. W. 2005. Diagnosis and population analysis of Pythium species using AFLP fingerprinting. Plant Dis. 89:81-89.

15. Goodwin, S. B. 1997. The population genetics of Phytophthora. Phytopathology 87:462-473.

16. Goodwin, S. B., Spielman, L. J., Matuszak, J. M., Bergeron, S. N., and Fry, W. E. 1992. Clonal diversity and genetic differentiation of Phytophthora infestans populations in northern and central Mexico. Phytopathology 82:955-961.

17. Goodwin, S. B., Sujkowski, L. S., Dyer, A. T., Fry, B. A., and Fry, W. E. 1995. Direct detection of gene flow and probable sexual reproduction of Phytophthora infestans in northern North America. Phytopathology 85:473-479.

18. Grau, C. R., Muehlchen, A. M., Tofte, J. E., and Smith, R. R. 1991. Variability in virulence of Aphanomyces euteiches. Plant Dis. 75:11531156.

19. Grünwald, N. J. 2003. Within field phenotypic and genotypic diversity in Aphanomyces euteiches. Pages 60-66 in: Proc. Second Int. Aphanomyces Workshop. N. J. Grünwald and C. J. Coyne, eds. Pasco, WA.

20. Grünwald, N. J., and Coyne, C. J. (eds.) 2003. Proc. Second Int. Aphanomyces Workshop. United States Department of AgricultureAgricultural Research Service, Pasco, WA.

21. Grünwald, N. J., and Flier, W. G. 2005. The biology of Phytophthora infestans at its center of origin. Annu. Rev. Phytopathol. 43:171-190.

22. Grünwald, N. J., Flier, W. G., Sturbaum, A. K., Garay-Serrano, E., van den Bosch, T. B. M., Smart, C. D., Matuszak, J. M., Lozoya-Saldaña, H., Turkensteen, L. J., and Fry, W. E. 2001. Population structure of Phytophthora infestans in the Toluca Valley region of Central Mexico. Phytopathology 91:882-890.

23. Grünwald, N. J., Goodwin, S. B., Milgroom, M. G., and Fry, W. E. 2003. Analysis of genotypic diversity data for populations of microorganisms. Phytopathology 93:738-746.

24. Hedrick, P. W. 2000. Genetics of Populations. Jones and Bartlett Publishers, Sudbury, MA.

25. Holub, E. B., Grau, C. R., and Parke, J. L. 1991. Evaluation of the forma specialis concept in Aphanomyces euteiches. Mycol. Res. 95:147-157.

26. Kraft, J. M., Marcinkowska, J., and Muehlbauer, F. J. 1990. Detection of Aphanomyces euteiches in field soil from northern Idaho by a wetsieving/baiting technique. Plant Dis. 74:716-718.

27. Leclerc, M. C., Guillot, J., and Deville, M. 2000. Taxonomic and phylogenetic analysis of Saprolegniaceae (Oomycetes) inferred from LSU rDNA and ITS sequence comparisons. Antonie Leeuwenhock 77:369-377.

28. Leipe, D. D., Wainright, P. O., Gunderson, J. H., Porter, D., Patterson, D. J., Valois, F., Himmerich, S., and Sogin, M. L. 1994. The stramenopiles from a molecular perspective: 16S-like rRNA sequences from Labyrinthuloides minuta and Cafeteria roenbergensis. Phycologia 33:369-377.

29. Ludwig, J. A., and Reynolds, J. F. 1988. Statistical Ecology: A Primer on Methods and Computing. John Wiley \& Sons, New York.

30. Lynch, M., and Milligan, B. G. 1994. Analysis of population genetic structure with RAPD markers. Mol. Ecol. 3:91-99.
31. Malvick, D. K., and Grau, C. R. 2001. Characteristics and frequency of Aphanomyces euteiches races 1 and 2 associated with alfalfa in the Midwestern United States. Plant Dis. 85:740-744.

32. Malvick, D. K., Grau, C. R., and Percich, J. A. 1998. Characterization of Aphanomyces euteiches strains based on pathogenicity tests and random amplified polymorphic DNA analyses. Mycol. Res. 102:465-475.

33. Malvick, D. K., and Percich, J. A. 1998. Genotypic and pathogenic diversity among pea-infecting strains of Aphanomyces euteiches from the central and western United States. Phytopathology 88:915-921.

34. Malvick, D. K., and Percich, J. A. 1998. Variation in pathogenicity and genotype among single-zoospore strains of Aphanomyces euteiches. Phytopathology 88:52-57.

35. Marra, R. E., Cortesi, P., Bissegger, M., and Milgroom, M. G. 2004. Mixed mating in natural populations of the chestnut blight fungus, Cryphonectria parasitica. Heredity 93:189-195.

36. Maynard Smith, J., Smith, N. H., O'Rourke, M., and Spratt, B. G. 1993. How clonal are bacteria? Proc. Natl. Acad. Sci. USA 90:4384-4388.

37. McDonald, B. A., Pettway, R. E., Chen, R. S., Boeger, J. M., and Martinez, J. P. 1995. The population genetics of Septoria tritici (teleomorph Mycosphaerella graminicola). Can. J. Bot. 73:S292-S301.

38. Milgroom, M. G. 1994. Population biology of the chestnut blight fungus, Cryphonectria parasitica. Can. J. Bot. 73:S311-S319.

39. Milgroom, M. G. 1996. Recombination and the multilocus structure of fungal populations. Annu. Rev. Phytopathol. 34:457-477.

40. Milgroom, M. G., Lipari, S. E., Ennos, R. A., and Liu, Y.-C. 1993. Estimation of the outcrossing rate in the chestnut blight fungus, Cryphonectria parasitica. Heredity 70:385-392.

41. Milgroom, M. G., Lipari, S. E., and Powell, W. A. 1992. DNA fingerprinting and analysis of population structure in the chestnut blight fungus, Cryphonectria parasitica. Genetics 131:297-306.

42. Mitchell, J. E., and Yang, C. Y. 1966. Factors affecting growth and development of Aphanomyces euteiches. Phytopathology 56:917-922.

43. Nei, M. 1973. Analysis of gene diversity in subdivided populations. Proc. Natl. Acad. Sci. USA 70:3321-3323.

44. Nei, M. 1978. Estimation of average heterozygosity and genetic distance from a small number of individuals. Genetics 89:583-590.

45. Nei, M. 1987. Molecular Evolutionary Genetics. Columbia University Press, New York.

46. Papavizas, G. C., and Ayres, W. A. 1974. Aphanomyces species and their root diseases in pea and sugarbeet. U.S. Dep. Agric. Res. Tech. Bull. 1485:1-158.

47. Peever, T. L., Salimath, S. S., Su, G., Kaiser, W. J., and Muehlbauer, F. J. 2004. Historical and contemporary multilocus population structure of Ascochyta rabiei (teleomorph: Didymella rabiei) in the Pacific Northwest of the United States. Mol. Ecol. 13:291-309.

48. Pfender, W. F., and Hagedorn, D. J. 1982. Aphanomyces euteiches f. sp. phaseoli, a causal agent of bean root and hypocotyl rot. Phytopathology 72:306-310.

49. Pilet-Nayel, M. L., Muehlbauer, F. J., McGee, R. J., Kraft, J. M., Baranger, A., and Coyne, C. J. 2002. Quantitative trait loci for partial resistance to Aphanomyces root rot in pea. Theor. Appl. Genet. 106:28-39.

50. Pilet-Nayel, M. L., Muehlbauer, F. J., McGee, R. J., Kraft, J. M., Baranger, A., and Coyne, C. J. 2005. Consistent quantitative trait loci in pea for partial resistance to Aphanomyces euteiches isolates from the United States and France. Phytopathology 95:1287-1293.

51. Schneider, S., Roessli, D., and Excoffier, L. 2000. Arlequin: A software for population genetics data analysis. Genetics and Biometry Lab, Department of Anthropology, University of Geneva, Geneva, Switzerland.

52. Scott, W. W. 1961. A monograph of the genus Aphanomyces. Va. Agric. Exp. Stn. Tech. Bull. 151:1-95.

53. Shang, H., Grau, C. R., and Peters, R. D. 2000. Evidence of gene flow between pea and bean pathotypes of Aphanomyces euteiches. Can. J. Plant Pathol. 22:265-275.

54. Shang, H., Grau, C. R., and Peters, R. D. 2000. Variation in virulence, host specificity, hyphal growth rate, and size of the aplerotic zone in successive single-zoospore and single-oospore progenies of Aphanomyces euteiches. Can. J. Plant Pathol. 22:160-165.

55. Simberloff, D. 1979. Rarefaction as a distribution-free method of expressing and estimating diversity. Pages 159-176 in: Ecological Diversity in Theory and Practice, J. F. Grassle, G. P. Patil, W. Smith, and C. Taillie, eds. International Co-operative Publishing House, Fairland, MD.

56. Simpson, E. H. 1949. Measurement of diversity. Nature 163:688.

57. Stoddart, J. A., and Taylor, J. F. 1988. Genotypic diversity: Estimation and prediction in samples. Genetics 118:705-711.

58. Swofford, D. 2000. PAUP*. Phylogenetic Analysis Using Parsimony (* and other methods). Sinauer Associates, Sunderland, MA.

59. Taylor, J. W., Geiser, D. M., Burt, A., and Koufopanou, V. 1999. The evolutionary biology and population genetics underlying fungal strain typing. Clin. Microbiol. Rev. 12:126-146. 
60. Taylor, J. W., Jacobson, D. J., and Fisher, M. C. 1999. The evolution of asexual fungi: Reproduction, speciation and classification. Annu. Rev. Phytopathol. 37:197-246.

61. Vos, P., Hogers, R., Bleeker, M., Reijans, M., van de Lee, T., Hornes, M., Frijters, A., Pot, J., Peleman, J., Kuiper, M., and Zabeau, M. 1995. AFLP: A new technique for DNA fingerprinting. Nucleic Acids Res. 23:4407-4414.

62. Webster, J. 1980. Introduction to Fungi. Cambridge University Press, Cambridge, UK

63. Weir, B. S., and Cockerham, C. C. 1984. Estimating F-statistics for the analysis of population structure. Evolution 38:1358-1370

64. Wicker, E. 2001. Diversité des populations françaises d'Aphanomyces euteiches Drechs., agent de la pourriture racinaire du pois: Variabilité pathogène et moléculaire. Ph.D. thesis, L'Ecole Nationale Supérieure Agronomique de Rennes, Rennes, France.

65. Wicker, E., Hullé, M., and Rouxel, F. 2001. Pathogenic characteristics of isolates of Aphanomyces euteiches from pea in France. Plant Pathol.
50:433-442.

66. Wicker, E., Moussart, A., Duparque, M., and Rouxel, F. 2003. Further contributions to the development of a differential set of pea cultivars (Pisum sativum) to investigate the virulence of isolates of Aphanomyces euteiches. Eur. J. Plant Pathol. 109:47.

67. Wicker, E., and Rouxel, F. 2001. Specific behaviour of French Aphanomyces euteiches Drechs. populations for virulence and aggressiveness on pea, related to isolates from Europe, America and New Zealand. Eur. J. Plant Pathol. 107:919-929.

68. Wright, S. 1943. Isolation by distance. Genetics 28:114-138.

69. Wright, S. 1978. Evolution and the Genetics of Populations. Volume 4. Variability Within and Among Natural Populations. University of Chicago Press, Chicago.

70. Zhan, J., Mundt, C. C., and McDonald, B. A. 2000. Estimation of rates of recombination and migration in populations of plant pathogens-a reply. Phytopathology 90:324-326. 